VOX PATRUM 22 (2002) t. 42-43

Ks. Norbert WIDOK

(Opole, UO)

\title{
POSTAWA GRZEGORZA Z NAZJANZU WOBEC ŚWIECKICH W ŚWIETLE JEGO LISTÓW PROTEKCYJNYCH
}

Adalbert Hamman, autor Portretów Ojców Kościoła ${ }^{1}$, uchodzący za wyśmienitego znawcę ich charakterów i osobowości, tak pisze o Grzegorzu z Nazjanzu: „Jego chorobliwa wrażliwość wciąż dawała znać o sobie. Potrzebował sympatii, może po prostu towarzystwa, obecności, jak wszystkie dusze udręczone"2. O duchowości Grzegorza w sposób najbardziej widoczny można wnioskować na podstawie analizy jego korespondencji. Pozostawione przez niego listy są świadectwem nie tylko jego rozlicznych kontaktów, ale przede wszystkim wskazują na wrażliwość duszy całkowicie przesyconej Ewangelią. Jego subtelność połączona $z$ imperatywem miłości chrześcijańskiej nakazywała mu dostrzegać drugiego człowieka, jego los i troski dnia codziennego. Sprawy potrzebujących to zawsze jego własne problemy. Kierując się tymi względami, Grzegorz zaczął pisać listy zaraz po swoim powrocie z Aten w roku 360 i redagował je do chwili swojej śmierci (390). W tym czasie powstało 245 listów, spośród których prawie połowa pochodzi z lat 381-383, kiedy to osiadł w rodzinnych stronach po opuszczeniu biskupstwa w Konstantynopolu.

Rzeczą niezwykle interesującą jest to, że Nazjanzeńczyk pisał listy w większości do osób świeckich, a nie duchownych. Skierował do nich 164 listy, wśród nich 18 do członków swojej rodziny (w niniejszym artykule nie będą one jednak brane pod uwagę) ${ }^{3}$. Wykaz świeckich adresatów obejmuje 65 pozycji. Jedni otrzymywali po jednym liście, inni po kilka, a nawet kilkanaście. W zależności od rozmaitych sytuacji adresatów, ich położenia życiowego i konkretnych potrzeb, a także i $z$ racji pełnionych funkcji w aparacie państwowym, w korespondencji Kapadocczyka można wyróżnić kilka grup listów: przeważającą ilość, bo czwartą część całej korespondencji, stanowią listy protekcyjne, ponad-

\footnotetext{
${ }^{1}$ A. Hamman, Portrety Ojców Kościola. Praktyczny przewodnik po patrologii, thum. zbiorowe, Warszawa 1978.

2 Tamże, s. 126.

${ }^{3}$ Adresatami tych listów byli: Cezariusz, brat (Ep. 7, 14, 20), Amfilochiusz, kuzyn (Ep. 9, 13, 25, 26, 27, 28), Nikobul, mąż siostrzenicy (Ep. 12, 51, 52, 53, 54, 55), Alipiusz, szwagier (Ep. 86), Walentynian, krewny (Ep. 203) oraz Melecjusz, mąż siostrzenicy (Ep. 240).
} 
to są też listy zawierające prośby we własnej sprawie, dowody przyjaźni, pouczenia odnośnie doskonałości, upomnienia, pocieszenia, pozdrowienia, a także listy wyrażające pochwalę i uznanie oraz wyjaśniające różnego rodzaju sytuacje własnej codzienności. Niezależnie od pozycji społecznej swoich adresatów, Grzegorz w listach pisanych do nich kieruje się miłością, godnością czlowvieka i przyjaźnią.

Przedmiotem analiz niniejszego artykułu są jedynie listy protekcyjne. Stanowią one największą grupę listów pisanych do świeckich, bo zawierającą 49 pozycji, oraz 9 listów pisanych do biskupów, których treścią są sprawy ludzi świeckich. W zdecydowanej większości adresowane są do urzędników państwowych, od których Grzegorz oczekiwal wsparcia i pomocy dla protegowanych. Czynił to w imię miłości chrześcijańskiej, wykorzystując do tego swoje talenty retoryczne. Listy te, niejednokrotnie okraszone pochlebstwami, stanowią $\mathrm{z}$ jednej strony arcydzieło sztuki epistolograficznej, z drugiej zaś świadectwo głębokiej wrażliwości i wyczucia. Każdy z listów, w zależności od osobowości adresata, cechuje się indywidualną atmosferą ducha. Kapadocczyk nie dąży do bezwzględnego spełnienia swej prośby, lecz daje adresatom możliwości okazania ich miłosiernych zachowań. Listy protekcyjne dzielą się na trzy grupy, w zależności od ich odbiorców, a więc adresowane są do urzędników (36 listów), przyjaciól (13 listów) oraz biskupów (9 listów) ${ }^{4}$. Adresaci wyróżnionych grup to w zdecydowanej większości przyjaciele Grzegorza, a więc osoby obdarzone przez niego zaufaniem i szacunkiem.

\section{LISTY DO URZĘDNIKÓW PAŃSTWOWYCH}

Kandydian, który przypuszczalnie był namiestnikiem Kapadocji, jest adresatem pierwszego listu protekcyjnego (Ep. 10) napisanego przez Grzegorza ok. 362 roku. Jest on właściwie listem pochwalnym, ułożonym według wskazań retoryki, w którym Grzegorz, popisując się kunsztem retorycznym, wychwala zalety adresata. Dopiero w końcowej jego fazie wyraża swe życzenie, kierując do namiestnika słowa:

„[...], byś kiedyś przy nas stanął i Bogu, byś był po stronie prześladowanych, a nie prześladowców, bo tamto wir czasu porywa, to zaś daje nieśmiertelne zbawienie"s.

List ten powstał za panowania cesarza Juliana, stąd też Grzegorz wstawia się za uciskanymi chrześcijanami.

${ }^{4}$ Informacje na ich temat zebrał w swym opracowaniu M.M. Hauser-Meury, Prosopographie zu den Schriften Gregors von Nazianz, Berlin 1960.

${ }^{5}$ Epistola (= Ep.) 10, PG 37, 41A, thum. J. Stahr (Poznań 1933), POK 15, 21 (pisownię i język przekładu nieco uwspólcześniamy). 
Tego samego roku Grzegorz kieruje list (Ep. 15) do Loliana, który prawdopodobnie był adwokatem; odwoluje się w nim do przyjaźni i wychwala zalety adresata. Pełen nadziei poleca swych siostrzeńców, Helladiusza i Eulaliusza, prosząc go następująco:

„Okaż się im wszysıkim: drogim przyjacielem, zacnym sąsiadem, dzielnym obrońca, krótko mówiąc, szlachetnym Lolianem, znanym z piękności duszy"”.

Prefekt Konstantynopola, Sofroniusz, pełniący swą funkcję w 369 roku, był odbiorcą aż 5 listów wstawienniczych, w których Grzegorz poleca sprawy osób mu znanych. Pierwszy z nich (Ep. 21) dotyczy krewnego Nikobula. Treść listu stanowi pochwała przymiotów adresata, która kończy się prośbą:

„Nikobulowi idź na rękę. W czym i w jakiej mierze? W tym, o co cię poprosi, w mierze, jaką uznasz, że przystoi twej wielkoduszności"?

Kapadocczyk zatem pragnie przez swą protekcję umożliwić Nikobulowi dostęp do prefekta w nadziei na spelnienie przez niego wszelkich próśb krewnego.

Natomiast Amfilochiusz, niesłusznie oskarżony o malwersacje finansowe, jest także przedmiotem troski Grzegorza (Ep. 22). Wydarzenia, jakie miały miejsce wokół tej sprawy, były jedynie pomówieniem, będącym następstwem ludzkiej zawiści. Kapadocczyk nie może być obojętny wobec tego faktu i zwraca się do Sofroniusza następująco:

„Nie ścierp tego, nie patrz obojętnie, jak go oszczerstwa szarpią! Nie! Proszę twej świętej i wielkiej duszy!"8.

Nie jest nam znany finał tej sprawy, jednak radykalny ton prośby z pewnością przyniósł oczekiwany skutek.

Smutek i rozgoryczenie ogarnęły Grzegorza, gdy dowiedział się o grabieży mienia po śmierci swego brata Cezariusza. Toteż opis szlachetności jego osoby i dokonanych czynów stał się treścią kolejnego listu (Ep. 29) kierowanego do Sofroniusza. Ten, będąc prefektem miasta, w którym Cezariusz mieszkał, w przeświadczeniu Grzegorza mógl okazać się skuteczny w przerwaniu fali napadów na mienie swego brata. Dlatego w końcowej jego części ze zbolalym sercem Grzegorz blaga o pomoc:

„Nie ścierp ty tego: współczuj, oburzaj się z nami - okaż serce zmarłemu Cezariuszowi. Zaklinam cię na przyjaźń samą, na nadzieje twoje, które sobie wyjednaj, okazując się wiernym i szczerym przyjacielem zmartego"".

Również w tym przypadku nie wiadomo, jaki skutek przyniosła ta protekcja.

\footnotetext{
${ }^{6}$ Ep. 15, PG 37, 48C, POK 15, 28.

${ }^{7}$ Ep. 21, PG 37, 56C, POK 15, 35.

8 Ep. 22, PG 37, 57B; POK 15, 36.

${ }^{9}$ Ep. 29, PG 37, 65A, POK 15, 43.
} 
Grzegorz świadom tego, że Sofroniusz pochodzi z Kapadocji, odwoluje się do ich wspólnych patriotycznycí uczuć, polecając mu młodego retora pochodzącego także $z$ Kapadocji. Çzyni to w kolejnym liście (Ep. 37) w następującycil stowach:

„,[...] Eudoksjusz zwraca się teraz do ciebie przeze mnie. Chciej imię swe jeszcze bardziej rozsławić i okaż życzliwość temu człowiekowi, w czymkolwiek poprosi cię o opiekę"10.

Czułe serce Grzegorza nie mogło pozostać obojętne po spotkaniu i bliższym poznaniu Amazoniusza. Dlatego Nazjanzeńczyk, chcąc okazać mu pomoc i jednocześnie zapewnić o przychylności, przedstawia go Sofroniuszowi. W liście do niego adresowanym (Ep. 39) snuje refleksje na temat przyjaźni i przyjaciót. Tam też swego adresata nazywa przyjacielem, licząc na względy wobec protegowanego Amazoniusza. Pełen zaufania Grzegorz pisze:

„Doszedilem do przekonania, że w zamian za wszystko inne tego jednego powinieneın mu użyczyć: twej przyjaźni i opieki [...], w zamian zaś przedstawiam mu, co mam najpiękniejszego: przyjacielo:vi - przyjaciól. Uważam zaś ciebie za pierwszego i najszczerszego wśród nich" ${ }^{11}$.

Tekst tego listu świadczy o wyjątkowej wrażliwości Grzegorza względem zalet innych ludzi. Te bowiem pobudzały go do działań wstawienniczych.

Do Cezariusza, będącego niegdyś prefektem Konstantynopola, a potem czlowiekiem bardzo wpływowym, Kapadocczyk w 369 r. skierował list (Ep. 23), w którym podejmuje sprawę Amfilochiusza, poruszaną już w wyżej omówionym liście do Sofroniusza; potępia w nim przewrotność i nieuczciwość, której ofiarą padł protegowany. Grzegorz, podkreślając zalety adresata wierzy, że jest on w stanie pomóc i dlatego prosi go:

„Więc nie ścierp, by złość górowala nad cnotą, i nie wzgardź moją siwizną; owszem, i świadectwo moje uwzględnij i laskawością swą uzasadnij me błogosławieństwa, znaczące może coś u Boga, przy którym stoję"12.

Następny list protekcyjny ( $E p .67)$, skierowany do urzędnika powstał dopiero po pięciu latach (ostatni przed udaniem się na stolicę biskupią do Konstantynopola), gdy w 374 r. Grzegorz wstawia się u Juliana, odpowiedzialnego za finanse, prosząc go o miłosierdzie. Obydwaj byli zaprzyjaźnieni z lat szkolnych, stąd też przejawia się w nim ton bezpośredniości. Grzegorz przynagla Juliana do okazania swej dobroci biednym i zwolnienia duchowieństwa $z$ konieczności płacenia podatków:

\footnotetext{
${ }^{10}$ Ep. 37, PG 37, 77C, POK 15, 53.

11 Ep. 39, PG 37, 80C-81A, POK 15, 55.

12 Ep. 23, PG 37, 60A, POK 15, 37.
} 
„[...] owszem, spełnij miłosierdzie, któreś obiecał biednym. A także i duchownych moich, o których prosiłem, uwolnij od opodatkowania; pomyśl, że to bardzo nie na miejscu, by inni całe mienie poświęcali Bogu, a tyś nie chciał nawet za darmo okazać się dobrym"13.

Oprócz złożonej prośby Grzegorz dołącza jej motywację, która w sposób bezpośredni dotykała ambicji Juliana.

W bardzo ostrym tonie biskup kapadocki zwraca się do urzędników Nazjanzu, którzy tamtejszego diakona usiłowali obłożyć podatkami. Grzegorz, po dwuletniej służbie biskupiej w stolicy, przybyl z nim prawdopodobnie do rodzinnego iniasta. Po krótkim czasie musial interweniować i pisze ( $E p$. 98) w 381 r. w jego sprawie w bardzo stanowczych słowach:

„Ale człowiekowi temu dla tych wszystkich przyczyn pokój dajcie, byście skarbowi niewiele przysporzywszy, wielkiej szkody sami nie ponieśli"14.

W latach 382-383 urząd prefekta Kapadocji Drugiej piastował Olimpiusz. Był on adresatem 13 listów kierowanych do niego przez Grzegorza, spośród których aż 7 zaliczyć należy do protekcyjnych. Na początek jego kariery urzędniczej przypadają 3 listy; w każdym z nich Nazjanzeńczyk poleca inną osobę. W pierwszym z nich (Ep. 104) wychwalając uprzejmość adresata oraz jego milosierdzie, przeprasza za listowne przedłożenie sprawy pewnej wdowy, o której wyraża się w następujący sposób:

„Wiodę oto przed ciebie nieszczęsną Filumenę, by pokloniła się twojej sprawiedliwości i przedstawiła ci te łzy, którymi moje serce kruszy. W czym krzywdy doznała i od kogo, sama ci wyjawi"15.

W przedłożonym liście Grzegorz wprawdzie nie wtajemniczył adresata w sedno sprawy, ale niewątpliwie umożliwił pokrzywdzonej osobie dostęp do łask urzędnika.

Grzegorz, obezwładniony chorobą, prosi listownie kapadockiego prefekta o milosierdzie i łaskawość. Protekcja tym razem dotyczy niejakiego Pawła, którego przedstawia w kolejnym liście ( $E p$. 105):

„Tylko Boga prosić i twoje miłosierdzie [...], byś nie odrzucił od ręki mojego wstawiennictwa, lecz lagodnie przyjął nieszczęśliwego Pawla"16.

Podobny ton cechuje następny list (Ep. 106) do Olimpiusza. Biskup kapadocki dziękuje za dotychczasowe względy i przedstawia mu swego krewniaka, nie opisując wprost jego sprawy, lecz jedynie polecając go prefektowi:

\footnotetext{
${ }^{13}$ Ep. 67, PG 37, 132BC, POK 15, 97-98.

${ }^{14}$ Ep. 98, PG 37, 172B, POK 15, 128.

15 Ep. 104, PG 37, 204C, POK 15, 154.

${ }^{16}$ Ep. 105, PG 37, 205B, POK 15, 154.
} 
„Oto inny znowu blagalnik, ten jeniec strachu, mój krewniak Eustratiusz, który zc mną i przeze mnie korzy się przed twạ dobrocią [...], a nie chce przez kogo innego do stóp ci przypaść, jeno przeze mnie, aby twego wspólczucia sobie przysporzyl"17.

Wymienione w przytoczonych listach osoby nie nalezały do ludzi wysoko postawionych w hierarchii społecznej, a więc nie stanowiły elity. Wstawiennictwo Grzegorza za tymi, którzy nie odznaczali się szczególnymi zasługami, lecz potrzebowali jedynie ludzkiego wsparcia, jest dowodem wielkoduszności i filantropii Grzegorza.

Listy Grzegorza nie dotyczyly tylko protekcji poszczególnych osób, lecz zawieraly także wstawiennictwo za całymi społecznościami. Tego typu przypadek mial miejsce w odniesieniu do mieszkańców Nazjanzu. Olimpiusz, jak nas informuje jeden $\mathrm{z}$ listów (Ep. 141), był gotów zburzyć miasto $\mathrm{z}$ tego powodu, że pewna grupa jego mieszkańców wywołala poważne zamieszki, przeciwstawiając się blizej nie określonym zarządzeniom władzy. Grzegorz $\mathrm{z}$ tychże racji prosi prefekta, by zastanowił się nad planowaną decyzją. Treść całego listu jest właściwie wołaniem o zlitowanie się nad żahującymi za swój czyn mieszkańcami Nazjanzu i jednocześnie nad autorem tego listu, któremu to miasto jest tak bardzo drogie. Oto krótki fragment tego błagalnego wołania:

„Czyż dlatego ma miasto przestać istnieć? Nie - mój drogi - nie podpisuj tego! Raczej uwzględnij blagania wszystkich obywateli, radców i urzędników; wiedz, że wszystkich jednako dotyka to nieszczęście, chociaż przez wzgląd na wielkość twej władzy cicho siedzą, w glębi rozpaczając"18.

W przytoczonym tekście, charakteryzującym się rozpaczliwym tonem, daje się zauważyć zdecydowane żądanie spelnienia prośby, graniczące wręcz z rozkazem. Grzegorz, mający doświadczenia służby biskupiej w Konstantynopolu, mógł widocznie pozwolić sobie na tak radykalne zwrócenie się do urzędnika.

Powyższej sprawy dotyczy także kolejny list (Ep. 142). Różni się on znacznie od poprzedniego: jest o wiele krótszy, a w treści przeważają elementy osobiste. Autor żali się z powodu nieugiętej choroby i jeszcze raz delikatnie przypomina o rzeczonej prośbie:

„Uczcij też i tę niemoc moją, do której przyczyniły się w części i znoje dla Boga podjęte - jeśli się godzi chwalić. Dlatego oszczędź radnych, którzy spoglądają na mnie jako na tego, co ma przystęp do ciebie"19.

Grzegorz swoje zaangażowanie w obronę Nazjanzu oparł na znajomości z Olimpiuszem, ciesząc się bez wątpienia jego sympatią.

\footnotetext{
17 Ep. 106, PG 37, 205C, POK 15, 155.

18 Ep. 141, PG 37, 241, POK 15, 185.

19 Ep. 142, PG 37, 244B, POK 15, 186.
} 
IVspomniana wyżej poufałość wobec prefekta stała się bodźcem do przesłania mu dalszej prośby, dotyczącej tym razem prezbitera Leoncjusza ( $E p$. 143). Grzegorz motywuje ją swoją wielkodusznością i zrozumieniem polożenia, w którym się znalazł. Treść tej protekcji brzmi następująco:

„Czy ty widzisz moją wielkoduszność? Sam potrzebuję twojej uprzejmości we własnych sprawach, a oręduję za innymi i nie boję się wyczerpać twojej dobroci cudzymi sprawami. [...] - to daruj już to mnie, i Bogu, i oltarzowi, i całemu zborowi duchowieństwa, do którego niegdyś się zaliczał"20.

O wielkości ducha biskupa świadczy fakt, że prezbiter Leoncjusz, mimo popełnienia znaczących przewinień, nie spotkał się z potępieniem, ale litościwym potraktowaniem Grzegorza.

Treść ostatniego listu protekcyjnego (Ep. 146), adresowanego do Olimpiusza, dotyczy Nikobula, krewnego Grzegorza. Zawiera on wyjaśnienie oszczerstwa rzuconego na jego osobę, które w swych konsekwencjach przybrało postać prawnego oskarżenia. Jedynie prefekt Kapadocji, odpowiedzialny także za działalność sądowniczą, mial możliwość ujawnienia prawdziwej strony przebiegu procesu. Grzegorz liczy na przychylność Olimpiusza, o którą prosi tymi oto słowami:

.Przeniknij lotnością ducha złośliwość, z której to wynika, i z czci dla mnie, twego chwalcy, okaż się milosiernym sędzią w poruszonej sprawie, bo nie tylko ludzi rozsądzasz dzisiaj, lecz także cnotę i złość, o które więcej, niż o jednostki, dbać powinni tówni ci w cnocie i prawi dostojnicy"21.

Biskup kapadocki dotyka bardzo delikatnej struny osobowości Olimpiusza: prawości i sprawiedliwości względem sądzonego człowieka. Niewątpliwie w taki sposób przeprowadzona przez Grzegorza argumentacja wskazuje na wielką znajomość psychiki ludzkiej.

Nikobul, otaczany przez niego troską wstawienniczą, stał się powodem napisania jeszcze dwóch listów, skierowanych do Asteriusza, współpracownika Olimpiusza. W pierwszym z nich (Ep. 147) obok myśli ukazujących, czym powinna być sprawiedliwość i odpowiedzialność, biskup kieruje do niego następujące slowa:

„Jego to powierzam twojej dłoni, a przez nią dłoni namiestnika, i uważam to za coś bardzo przykrego, bym innych swym wpływem od największych oskarżeń uwalniał, a w pierwszym rzędzie teraźniejszych srogich oskarżycieli, jego zaś nie mógł nawet od oszczerczej napaści"22.

Asteriusz został więc powiadomiony o przykrej sprawie rodzinnej. Przy tej okazji Grzegorz - jak wynika $z$ tekstu - wyznaje, że często bierze w obronę

\footnotetext{
20 Ep. 143, PG 37, 245A, POK 15, 187.

21 Ep. 146, PG 37, 249C-252A, POK 15, 191.

${ }^{22}$ Ep. 147, PG 37, 252BC, POK 15, 192.
} 
niewinnych, nawet tych obarczonych największymi oskarżeniami. Takie podejście świadczy o niezwykłej wrażliwości Grzegorza na niesprawiedliwość, której wielu doświadcza, a której on nie potrafit tolerować.

Natomiast drugi list dotyczący Nikobula (Ep. 148) zawiera motywację prośby Grzegorza, która niewątpliwie stanowi popis sztuki retorycznej. Adresat, czytając go, nie mógł nie ulec naleganiom biskupa, a zwłaszcza stanowczenuu błaganiu:

,Jak tu milczeć i nie być natrętnym, choćbyś filozofem był! Podaj rękę uciśnionym. by i tobie Bóg ją podal - jako człowiek jej potrzebujesz! Użyj całej przyjaźni, rozumu i wplywu z pomocą Bożą w naszej sprawie!"23.

Niesprawiedliwe oskarżenie Nikobula spowodowało niebywałe zdeterminowanie biskupa do dzialania. Wierzy w przyjaźń, która łączyła go z Asteriuszem. Podtrzymywana ona była nieustanną korespondencją, o której wspomina iv innym liście (Ep. 150), gdzie jest mowa także o dobrodziejstwach, jakich vielu doznało za sprawą interwencji Nazjanzeńczyka. Tym razem kieruje prośbę do Asteriusza, wstawiając się za diakonem Georgiuszem:

„[...] wręczam ci przez ten list mego brata i współdiakona Georgiusza, męża wybranego przeze mnie, a Kościołowi bardzo użytecznego, z życzeniem, by znalazł w tobie oparcie w sporze z pewnymi ludźmi i nie uległ tyrańskiej przemocy"24

Również ten list jest świadectwem zaufania do człowieka świeckiego, skoro biskup powierza mu sprawy swego diakona.

Grzegorz odznaczał siç też wielką troską o Kościół Boży. Na sercu leżala mu przede w'szystkim kwestia odpowiedzialności biskupów za pełnione zadania pasterskie. $Z$ racji mającego się odbyć w Konstantynopolu synodu w 382 roku, Nazjanzeńczyk wysyła 4 listy do świeckich dostojników, by zaangażowali się w pokojowy przebieg tego zebrania biskupów. W pamięci Grzegorza tkwi jeszcze bardzo głęboko wydarzenie, które mocno go dotknęło, kiedy to na podstawie pretensji biskupów zebranych na soborze w Konstantynopolu w $381 \mathrm{r}$. względen jego osoby, odnośnie zasiadania tam na stolicy biskupiej jako drugiej po Sazimie, musiał opuścić to miasto. Ponadto nie mógł znieść niepotrzebnych kłótni i popisów retorycznych biskupów w sprawach odnoszących się do Bożych tajemnic, jakich on jako biskup Konstantynopola musiał wysłuchiwać w czasie obrad soborowych. Tym razem Nazjanzeńczyk z tych właśnie powodów, jak i ze względu na zly stan swego zdrowia, rezygnuje $\mathrm{z}$ uczestnictwa w obradach ${ }^{25}$, wykazując jednocześnie przeogromną odpowie-

${ }^{23}$ Ep. 148, PG 37, 253A, POK 15, 193.

24 Ep. 150, PG 37, 256B, POK 15, 194.

${ }^{25}$ O swej rezygnacji Grzegorz poinformowal ponadto swego przyjaciela Prokopiusza, którego sam cesarz Teodozjusz powiadomił o tym, że cieszylby się z obecności Kapadocczyka w czasie synodu (zob. Ep. 130, POK 15, 172) oraz Olimpiusza, prefekta Kapadocji Drugiej, wysyłając mu 
dzialność za ich przebieg poprzez powiadomienie urzędników państwowych $o$ istocie swej troski.

Pierwszym z nich jest Saturnin, general wojskowy na Wschodzie. Grzegorz prosi go w liście (Ep. 132), by jako człowiek powołany do utrzymywania porządku publicznego, zechciał też zatroszczyć się o zgodę wśród biskupów:

„Tym, ile tylko zdołasz, nie wahaj się i slowem i czynem zaszczepić spoleczną zgodę, bo oto znowu synod biskupów i zncwu obawa, byśmy się teraz wstydzić nie musieli, jeśli i ten będzie miał przykry koniec, jak poprzedni" ${ }^{26}$.

Biskup kapadocki jest pełen obaw odnośnie zachowania się biskupów, dlatego nie waha się włączyć nawet czlowieka świeckiego w pomyślny przebieg synodu.

W tę samą sprawę wtajemniczył Grzegorz także Wiktora, generała wojskowego (Ep. 133). Najpierw informuje go o swoim pobycie na wsi, gdzie leczy swe schorowane ciało, a potem przechodzi do kwestii, na której mu zależy najbardziej: ochrony synodu przed nieprzyjaciółmi zewnętrznymi, czyli Gotami. Przedkładany zaś generałowi problem kończy prośbą:

„,[...] przeto przyczyń się do powszechnego uspokojenia, bo wszak nie jesteś najlichszą cząstką Kościoła, i nie pozwól wszystkiemu spopieleć w pożarze, ogarniającym dziś Kościól”27.

Treść tego listu świadczy niewątpliwie o zaufaniu, jakim biskup darzył czlowieka świeckiego, dokumentując tym samym dobrą wówczas współpracę duchowienístwa ze świeckimi.

Sofroniusz, prefekt Konstantynopola z 369 r., będący adresatem już 5 listów, w których Grzegorz polecal mu swych bliskich, jest odbiorcą kolejnego (Ep. 135), lym razem dotyczącego również synodu w Konstantynopolu. Autor pragnie i jego zaangażować w pomyślny przebieg obrad synodalnych. Grzegorz musiał darzyć Sofroniusza wielką ufnością, skoro powierza mu sprawy kościelne:

„Wy zaś - zaklinam - dolóżcie wszelkich starań, by przynajmniej teraz, jeśli nie pierwej, połowice okręgu ziemskiego, smutnie rozdzielone, się zgrały i w jedno zeszły, a zwłaszcza jeśli zastaniecie ich poróżnionych nie z powodu nauki wiary, lecz własnej maloduszności, jakem to sam zauważył" ${ }^{28}$.

W tym liście Nazjanzeńczyk nawiązuje do wydarzenia, które miało miejsce w czasie obrad Soboru Konstantynopolitańskiego (381), kiedy to po śmierci Melecjusza pojawiły się dwie frakcje co do wyboru następcy. Po roku nic się w tej kwestii nie zmieniło, stąd uporczywa prośba Grzegorza.

odmowny list na jego zaproszenie do wzięcia udziału w tym synodzie (zob. Ep. 131, POK 151, 173-174).

\footnotetext{
${ }^{26}$ Ep. 132, PG 37, 228B, POK 15, 174.

${ }^{27}$ Ep. 133, PG 37, 229C, POK 15, 176.

${ }^{28}$ Ep. 135, PG 37, 232A, POK 15, 177.
} 
Czwarty świecki dostojnik wtajemniczony przez Grzegorza w sprawy związane ze wspomnianym synodem to Modariusz. Również on był generałem wojskowym, mającym niemałe osiągnięcia militarne, znane autorowi listu. Stąd też został jego adresatem ( $E p .136)$ i tym samym pełnej troski prośby:

„Walcz, ile od ciebie zależy, o to, by biskupi na zjeździe doszli do pokojowego porozumienia. Bo schodzić się często, a nie wynaleźć kresu zła, owszem dodawać zawsze zamęt do zamętu - to tym większa hańba; przyznasz to sam"29.

Modariusz, podobnie jak pozostali adresaci listów dotyczących synodu, rozumieli z pewnością doskonale intencje Grzegorza, gdyż jako urzędnicy i mieszkańcy Konstantynopola byli zorientowani w przebiegu i postanowieniach soboru z 381 roku.

Biskup kapadocki oprócz listów, przedstawiających kwestie ściśle kościelne, skierowanych do wymienionych dostojników, zwracał się także do nich w sprawach prywatnych. Te adresowane do Olimpiusza zostały juz wyżej omówione. Pozostali otrzymali po jednym liście. Prawie jednocześnie z poprzednim Grzegorz pisze do Wiktora (Ep. 134). Jest to bardzo krótki list: zawiera pozdrowienie, zapewnienie o przyjaźni i polecenie Hyperechiusza, „którego - jak zwraca się do Wiktora biskup - jestem pewny, uczcisz, i ze względu na jego charakter, gdy człowieka poznasz, i ze względu na mnie, któremu postanowiłeś we wszystkim sprzyjać" ${ }^{30}$. Wprawdzie nie zostały podane konkretne zadania do wypełnienia, jednak prośba wstawiennicza była niewątpliwie wielką przysługą, jaką Grzegorz wyświadczył Hyperechiuszowi.

W tym samym czasie, a więc przed planowanym synodem, równie krótki list (Ep. 137) otrzymał Modariusz. Grzegorz poleca w nim Teodora, bliskiego mu człowieka, który jednocześnie był doręczycielem, a prośba w nim zawarta jest jednoznaczna:

„Racz go mile przyjąć - po części i ze względu na mnie: jest on i moim i twoim, moim domownikiem, a twoim wojakiem"31.

$\mathrm{Z}$ tego powodu, że Modariusz był generałem wojskowym, Grzegorz dla swego domownika, jak się wyraził w liście, pragnie jego przychylności i serdeczności wobec młodzieńca, który zamierza zostać żołnierzem.

Natomiast Saturnin był generałem wojskowym, a w roku 383 piastowal urząd konsula. Grzegorz ceni tę służbę państwową, ale także i przyjaźń, która ich łączyła. Dziękując za wyświadczone dobra, biskup poleca konsulowi Eudoksjusza (Ep. 181):

\footnotetext{
${ }^{29}$ Ep. 136, PG 37, 232C, POK 15, 178.

${ }^{30}$ Ep. 134, PG 37, 229C, POK 15, 176.

31 Ep. 137, PG 37, 233A, POK 15, 179.
} 
„[...] racz go w ogóle mile przyjąć i pieczę swą zaszczycić we wszystkim, w czym twej szlachetności będzie potrzebowal. Ja zaś odplacę się modlitwami”" 32 .

Prośba nie dotyczy konkretnej sprawy, często przykrej w swych skutkach, lecz jest poleceniem młodego czlowieka, który mając zapewnioną opiekę urzędnika, może ze spokojem realizować swe plany życiowe.

Tego samego roku Grzegorz interweniuje u innego generała wojskowego, a mianowicie Ellebichusa, z którym zaprzyjaźnił się w Konstantynopolu. Tym razem prosi go o zwolnienie ze slużby wojskowej lektora Mamanta (Ep. 225):

,Zostaw go Bogu i mnie, nie zaliczaj go do zbiegów i daj mu pisemne zwolnienie, żeby $i$ inni go nie zaczepiali" ${ }^{33}$.

Dla dobra protekcji i jej dalszych konsekwencji biskup odważa się nawet sugerować generałowi, jakie powinien przedsięwziąć środki. Z jednej strony świadczy to o dużej zażylości $z$ urzędnikiem państwowym, $z$ drugiej natomiast ukazuje stosunek Grzegorza do mlodego człowieka, na którym biskupowi bardzo zależy.

W 383 r. cesarz Teodozjusz zwolał kolejny synod do Konstantynopola. $\mathrm{Z}$ pewnego listu (Ep. 173) wynika, że Grzegorz nie jest do końca zorientowany, w jakim celu spotykają się biskupi. Jednak i tym razem troska o losy Kościoła nie pozwala mu milczeć. Prefektem Konstantynopola był wówczas Postumian, którego Grzegorz poznał bliżej w czasie swego biskupstwa w stolicy i który stał się adresatem listu w sprawie synodu. Oto słowa jego prośby:

„Wiedz, że nic tak nie przystoi twojej wladzy [...] jak to, by pod tobą i przez ciebie Kościoły pokoju zaznały, choćby wypadlo ostrzej wyłajać zwaśnionych"34.

Nazjanzeńczyk miał prawdopodobnie na uwadze schizmę melecjańską. Nie mógł pogodzić się z myślą, że Kościół, któremu służy, jest dotknięty skazą. $\mathrm{O}$ pomoc $\mathrm{w}$ tej sprawie prosił człowieka świeckiego.

W ostatnich latach życia Grzegorz osiadł w swych posiadłościach rodzinnych. Wówczas jego korespondencja protekcyjna w przeważającej części ograniczala się do Kapadocji. Tam miał przyjaciól, bliską mu rodzinę, a przede wszystkim znane mu były wydarzenia związane $\mathrm{z}$ ich życiem, w którym po części partycypował. $\mathrm{Z}$ tego okresu pochodzi kilka listów adresowanych do namiestników i urzędników Kapadocji, których także darzył zaufaniem. Jednym z nich był namiestnik Kapadocji - Grzegorz (Ep. 195). Powodem napisania tego listu była troska biskupa względem najbliższej jego rodziny i obawa, że odnowią sic̨ krzywdzące opinie odnoszone niegdyś do Nikobula, a teraz - po

${ }^{32}$ Ep. 181, PG 37, 296B, POK 15, 223.

${ }^{33}$ Ep. 225, PG 37, 369A, POK 15, 273-274.

${ }^{34}$ Ep. 173, PG 37, 284B, POK 15, 214. 
jego śmierci prawdopodobnie w 385 roku - do wdowy po nim Alipiany i jej dzieci. Po wstępie, zawierającym ukłony skierowane do namiestnika oraz zapewnienie o przyjaźni, prosi go o urzędową opiekę nad pozostałymi członkami rodziny:

„Poruczam ci prawicą moją Nikobula mojego z jego braćmi, nie żeby karę poniósł, lecz żeby do niej pociągnął innych, poruczam ci owdowiałą przedwcześnie matkę ich i dom niegdyś świetny i podziwiany"35.

Grzegorz, powodowany przyjaźnią i zaufaniem względem urzędnika, powierza mu losy swej najbliższej rodziny, odsłaniając sprawy raczej drażliwe i poufne.

Problem rodziny Nikobula, nad którym Grzegorz tak bardzo bolał, powierzyl także Hekeboliuszowi, innemu namiestnikowi Kapadocji. Jest to list (Ep. 196), w którym biskup wylewa swą gorycz i jednocześnie okazuje śmiałość w sformułowaniu prośby, będąc pełen nadziei na okazanie dobroci przez adresata:

„Więc jeśli pragniesz uczynić mi coś dobrego, duszo dobrocią tryskająca, z ufnością przyprowadzam do ciebie dom opłakany i miłosierdzia godny, wdowę z sierotami, gorącymi jeszcze od łez - mówię o siostrze mojej i jej dzieciach"36.

Następnie biskup wychwala zasługi Nikobula, jakie oddal innym poprzednim namiestnikom, a także państwu. Bardzo głęboko zatem Grzegorz musiał przeżywać odejście Nikobula oraz sytuację jego rodziny, skoro tak familiarne fakty powierzał świeckiej osobie.

Nemezjusz, prefekt Kapadocji, był odbiorcą dwóch kolejnych listów protekcyjnych, wysłanych przez Nazjanzeńczyka prawdopodobnie w 386 roku. Pierwszy z nich dotyczy jego krewnego Walentyniana (Ep. 198). Nie wynika $\mathrm{z}$ niego wprost, czy to on faktycznie zawinil, skoro musial ponieść karę, i stąd wstawiennictwo Grzegorza:

„[...] więc nie chciej karać $\mathbf{i}$ Walentyniana, tego twojego i mojego - za krewnym oręduję - lecz w słowach tylko nastraszywszy grzywną, zaniechaj karania. Bo nie za własne nawet niedbalstwo - jeśli wolno śmiało mówić - ponosi on karę. [...] pomóż w biedzie człowiekowi, mocno zgnębionemu tym przypadkiem" ${ }^{37}$.

W wydarzeniu, które stało się udziałem Walentynjana, biskup kapadocki dostrzega jedynie niedbalstwo, dzielone także przez innych. $Z$ tej to wlaśnie przyczyny odważył się interweniować w powyższej sprawie u prefekta i jako biskup błagać o litość.

W drugim liście adresowanym do Nemezjusza (Ep. 199) Nazjanzeńczyk wstawia się za Teodozjuszem. Będąc świadomy życzliwości i wspólnych zain-

\footnotetext{
${ }^{35}$ Ep. 195, PG 37, 320A, POK 15, 240.

36 Ep. 196, PG 37, 320C, POK 15, 241.

37 Ep. 198, PG 37, 325A, POK 15, 244.
} 
teresowań, o których wspomina, jest również przekonany, że prefekt okaże się osobą mu życzliwą i wrażliwą społecznie. Prośbę swą przedstawia w sposób następujący:
„Znowu najczcigodniejszy syn mój Teodozjusz przybywa przed twą światlość, Teodozjusz mój i twój, mój dla celu, o który chodzi, twój - jako twój blagalnik. Przybywa w żałosnej sprawie: sieroty w niebezpieczeństwie - dola człowiecza ku czemu tymczasem się stoczy, nie wiadomo [...]. Podaj dłoń niedoli, którą sam zbadasz ${ }^{\prime 38}$.

Nie sposób z listu wywnioskować, jakie sieroty Grzegorz miał na myśli. Prawdopodobnie chodziło o sierociniec, którym opiekował się Teodozjusz, a którego egzystencja została zachwiana biedą finansową. Dlatego obydwaj liczą na przychylne zbadanie sprawy powierzonej prefektowi.

Kolejny namiestnik Kapadocji, Jakub, który swe rządy sprawował prawdopodobnie po Nemezjuszu, czyli w 386 lub 387 roku, również był adresatem dwóch listów protekcyjnych. Ich treść wzajemnie się uzupełnia, ponieważ dotyczy tej samej kwestii: opieki nad Symplicją, wdową po Alipiuszu. Z treści pierwszego (Ep. 207) wynika, że Grzegorz po jego napisaniu wręczył go Symplicji, a ta udała się wraz z nim do namiestnika. Gotów był sam wybrać się do niego, lecz z powodu choroby zwrócił się do niego pisemnie:

„Najzacniejszą córę moją Symplicję, niegdyś żonę szlachetnego Alipiusza, który był ozdobą całej naszej ojczyzny, przyprowadzam do twej szlachetności z żałosnymi mianami wdowieństwa i sieroctwa, by znalazła u ciebie sprawiedliwość, w czym będzie twej pomocy potrzebowała. Spójrz tylko na ogrom nieszczęścia”39.

To tylko fragment błagalnej prośby biskupa o wstawiennictwo, zawierającej sugestie, jak adresat mógłby się do niej ustosunkować. W ten sposób Grzegorz pragnie wręcz wymóc na nim odwagę troszczenia się o sieroty, którymi zajmowała się Symplicja po śmierci swego męża. Jej opieka nad sierotami i wrażliwość Grzegorza na kwestie społeczne to fakty, które mają skłonić Nemezjusza do czynów milosiernych.

O to samo Grzegorz apeluje w drugim liście (Ep. 208), wyslanym bezpośrednio do namiestnika, w którym chwali adresata za jego szlachetność, serdecznie pozdrawia, i mimo, że nie poznał go osobiście, ośmiela się powtórzyć swą prośbę, wyjaśniając przy tym jej powód:

„Opuścił nas podziwu godny Alipiusz, orędownik przyjaciół i opiekun sierot. Niemały to dla mnie cios. Do tego przylącza się, ze dostojna wdowa po nim kłopotać się musi o sieroty. Pociesz ją dziś twym miłosierdziem, wyjednaj bezpieczeństwo dzieciom swoim przez to dobrodziejstwo dla sierot" ${ }^{\text {,40 }}$.

\footnotetext{
${ }^{38}$ Ep. 199, PG 37, 325C-328A, POK 15, 245.

39 Ep. 207, PG 37, 344A, POK 15, 256.

40 Ep. 208, PG 37, 345A, POK 15, 257.
} 
Treść obydwóch listów ukazuje pełny obraz sprawy, o którą w imieniu Symplicji zabiegał biskup kapadocki. Miało to miejsce na kilka lat przed jego śmiercią, kiedy był już schorowany i osłabiony. Nie szczędzil jednak resztek swych sil, by pomnażać wśród bliźnich dobro, angażując do tego nawet urzędników państwowych.

$\mathrm{Z}$ tego samego czasu pochodzi list (Ep. 211) Grzegorza adresowany do Cyriaka, który prawdopodobnie był urzędnikiem podatkowym. Biskup przedstawia w nim sytuację materialną przytułku, którym zarządzal jego prezbiter Sacerdos. W darze jako wsparcie dla sierot otrzymał od Kastora dwie posiadłości, które Cyriak zamierzal opodatkować. Z tej racji Grzegorz ośmiela się w tej sprawie prosić go o wspaniałomyślność:

„Jeśli uwolnisz je od wszelkiej krzywdy wniesiesz nie najmniejszy udział wyposażenia dla biednych i nagrody dla siebie, która - jak wiesz - nie ominie pobożnych" ${ }^{\text {"41 }}$.

List do Cyriaka to kolejne świadectwo wrażliwości biskupa na los pokrzywdzonych. Sam kierując się miłosierdziem chrześcijańskim, uczy go i wymaga tego od innych.

\section{LISTY DO PRZYJACIÓE}

Grzegorz nie mógł zachować się obojętnie wobec trudnej sytuacji Amfilochiusza, w którą uwikłał się nie będąc winnym. Jego ojciec był retorem, znanym zarówno Grzegorzowi, jak i Temistiuszowi, który stał się adresatem listu (Ep. 24) z 369 roku. Powolując się na przyjaźń, jaka ich łączyła, Nazjanzeńczyk przywołuje także wzniosłe myśli Platona i to, czym jest filozofia. Ufny w gesty dobroci adresata błaga:

„Podaj rękę będącemu w potrzebie: upomnij wedle słuszności i wspomóż. Nie móglbyś lepiej w duchu filozofii postąpić, niż współwalcząc teraz w obronie sprawiedliwości. Ponadto wyświadczasz tym dobrodziejstwo i mnie, twemu chwalcy, ipozwól to powiedzieć - przyjacielowi"42.

Temistiusz był poganinem, dlatego Grzegorz dla podkreślenia sensowności swej prośby odwołuje się do filozofii, a nie do wartości chrześcijańskich.

Tego samego roku Temistiusz odebrał drugi list (Ep. 38) od Grzegorza w bardzo podobnej sprawie. Tym razem słynnemu retorowi poleca młodego Eudoksjusza. Grzegorz z jego ojcem utrzymywał przyjazne stosunki. Życzliwość dla obu spowodowała, że w liście tym pisał:

\footnotetext{
41 Ep. 211, PG 37, 348C, POK 15, 260.

42 Ep. 24, PG 37, 60BC, POK 15, 38.
} 
„Co mu dobrego wyświadczysz, to jakbyś mnie samemu, a przez to uczcisz takize to, z czego siyniesz: wymowę - zechciej przeto popchnąć go naprzód. Trzeba, by dal się poznać jako mówca i z wymowy utrzymanie czerpal"43.

List adresowany do Tekli (Ep. 57), siostry Sacerdosa, pochodzący prawdopodobnie z 379 r., ukazuje wrażliwość Grzegorza na potrzeby człowieka, nawet te przyziemne. Prosi w nim bowiem o wino dla robotników, zatrudnionych przy wznoszeniu ogrodzenia wokół kościola:

„Nie mogąc ich pokrzepić górskim napojem, uciekam się do twej pełnej winogron prawicy, byś kazała źródłom strugami na nas spłynąć. Jeśli to rychło uczynisz, pokrzepisz wyschłe usta wielu, a przede wszystkim mnie... attyckiego natręla"44.

Kierowana do Tekli prośba, oprócz dobroci Grzegorza w stosunku do robotników, ukazuje także nieco żartobliwy charakter wstawiennictwa, bo przecież adresat nie jest urzędnikiem, lecz kimś bliskim.

Kolejne listy protekcyjne adresowane do przyjaciół zostały przez Grzegorza zredagowane dopiero po jego powrocie z Konstantynopola, gdzie przez dwa lata zasiadal na stolicy biskupiej. Tam poznał Palladiusza, retora ateńskiego, powołanego na służbę na dworze cesarskim. Grzegorz w liście (Ep. 103) skierowanym do niego w 381 r. wspomina wspólnych przyjaciól, cieszy się ze wzajemnej przyjaźni oraz ceni jego charakter. W dalszej części listu umieszcza prośbę, której treść dotyczy jego siostrzeńca:

„Frzyprowadzam ci znowu błagalnika Eufemiusza i znowu błagam, nie tylko byś życzliwie przyjąl mlodzieńca i wybaczył mu opieszałość, bo zawiadując sprawami sierot, z konieczności krzątał się około domostwa - lecz i zechciej poprowadzić to dalcj" ${ }^{45}$.

List ten wiózł ze sobą do Konstantynopola sam protegowany Grzegorza. Polecana więc sprawa musiała być wielkiej wagi. Dlatego biskup, ufny wv więzy przyjaźni, jest przekonany o pozytywnym jej rozwiązaniu, gdyż tak bardzo leżala mu na sercu dola polecanych sierot.

Palladiusz okazał wiele dobroci Grzegorzowi. Wynika to $\mathrm{z}$ relacji, jaką biskup rozpoczął drugi list (Ep. 170) do niego adresowany. Treść jego jest bardzo krótka: po podziękowaniach następuje powierzenie adresatowi Sacerdosa, wspólprezbitera Grzegorza, który w sprawach osobistych wybierał się do stolicy. Ta jego wyprawa stała się okazją, by Palladiuszowi sprawić przyjacielską radość. Nazjanzeńczyk kończy list słowami:

,[...] nie wiem, czym móglbym się więcej przyslużyć, niż zaznajamiając go $z$ twoją przezacnością",

${ }^{43}$ Ep. 38, PG 37, 80BC, POK 15, 54.

44 Ep. 57, PG 37, 112B, POK 15, 83.

45 Ep. 103, PG 37, 204AB, POK 15, 153.

46 Ep. 170, PG 37, 280B, POK 15, 211. 
I ten list wskazuje na wielkie zaufanie do przyjaciela, który jest człowiekiem świeckim, by ten zaopiekował się prezbiterem, współpracownikiem Grzegorza.

Prokopiusz to przyjaciel Grzegorza z czasów służby biskupiej w Konstantynopolu. Otrzymał on w $382 \mathrm{r}$. dwa listy wstawiennicze. W pierwszym (Ep. 128) przedstawia sylwetkę Antimusa, czlowieka zasłużonego dzięki sławnej wyprawie, o której biskup nie wspomina. $\mathrm{Z}$ tego to właśnie powodu Grzegorz pragnie, by Antimus wybierając się do stolicy, dzięki jego wstawiennictwu poznał Prokopiusza, tak zaś motywuje swój zamysł:

„Przynosicielowi tego listu, synowi memu Antimusowi, należy się za wielką rzecz wielka nagroda. Jaka? Zyskanie obrony twej, w czym jej będzie potrzebowat"47.

Jak wynika z listu, życzliwość Nazjanzeńczyka wobec drugiego człowieka była ogromna. Wystarczył mały pretekst, by zamienić go w dobrotliwy czyn. Więzy przyjacielskie z Prokopiuszem umożliwiły wyświadczenie przysługi Antimusowi, a przecież zarówno pierwszy, jak i drugi, byli ludźmi świeckimi, co wcale nie przeszkadzało Grzegorzowi w prośbach o wsparcie.

Podobnie, tego typu przeszkody nie towarzyszyły biskupowi kapadockiemu, gdy wtajemniczał Prokopiusza w sprawę, która wydarzyła się osobie duchownej. W drugim liście (Ep. 129) do niego adresowanym wstawia się za swoim diakonem, który z racji na zażyłość z bezbożnym Regianem wpadł w niełaskę. Nawiązując zaś do tej rzekomej zażyłości, Grzegorz pisze w ten oto sposób:

„Jeśli zaś uważasz ją za występek, to ze względu na Boga, któremu służy, i na moją siwiznę, którą, jak wiem, wielu ludzi bogobojnych poważa, okaż tę łaskę, błagam, i mnie i całemu duchowieństwu - poprzyj swoje nadzieje w Bogu przez uwolnienie tego człowieka od napaści" ${ }^{48}$.

Przyjaciel biskupa musiał zatem pełnić ważną funkcję, może w sądownictwie, skoro prosi o rozważną ocenę występku diakona.

W latach 383-385 powstały listy adresowane do retora Eudoksjusza, którego jako młodzieńca kilkanaście lat wcześniej Grzegorz polecał Sofroniuszowi i Temistiuszowi. Tym razem biskup kapadocki w trzech listach (Ep. 175, Ep. $176, E p .177)$, zwraca się do niego o roztoczenie opieki nad Nikobulem. Listy te zawierają ponadto myśli dotyczące adresata, wówczas młodego retora, opis jego zdolności, postępu w cnocie i żartobliwą wymianę zdań. W każdym $\mathrm{z}$ nich postacią centralną jest osoba Nikobula, o którym tak pisze do Eudoksjusza:

„[...] jakoś leniwy jest i potrzebuje bodźca - przeto od siebie dolóż gorliwości”49

[...] Poruczam ci znowu mego najsłodszego syna Nikobula. Racz go przyjąć ode

47 Ep. 128, PG 37, 221C, POK 15, 170.

${ }^{48}$ Ep. 129, PG 37, 224C, POK 15, 171-172.

${ }^{49}$ Ep. 175, PG 37, 285C, POK 15, 216. 
innie, ale jak ode mnie, użyczając szczodrze sztuki retorycznej ze względu na ojca chłopca, a umiejętności sofistycznej ze względu na mnie" ${ }^{\text {50 }}$. [...] a zaś cnemu Nikobulowi okaż się takim, jak się spodziewam. A jeśli i więcej zażądam, nienasyconość moją - człek szczodry - zaspokój”"51.

Przytoczone cytaty świadczą o wielkim zaangażowaniu i trosce Grzegorza o wyksztalcenie Nikobula i potwierdzają jego ustawiczną gotowość udzielania pomocy innym. Ponadto wymienione listy wskazują na bliską więź, jaka łączyła go $\mathrm{z}$ retorem.

Nazjanzeńczyk wykształcenie Nikobula powierzał także sofiście Stagiriuszowi w liście (Ep. 188) napisanym ok. 384 roku. Był on przyjacielem biskupa, stąd zażyłość obecna w liście, gdzie autor w sprawie Nikobula wypowiada się w następujących słowach:

.Jemu to okażesz dobroczynnie i wiedzę swoją i przyjaźń ku mnie, jeśli ci ona na sercu leży"

Powierzanie młodych adeptów sztuki sofistycznej starym doświadczonym retorom należy potraktować jako kolejną troskę Grzegorza, któremu zależalo na nieustannym rozwoju tej sztuki.

Powyższy list to nie jedyny przypadek takiej protekcji, bo oto sofista Eustochiusz rok wcześniej otrzymal analogiczny ( $E p .189$ ) o podobnej treści. Tym razem protegowanym jest Pronojos. Grzegorz chlubił się zdobytymi umiejętnościami retorskimi i z tego względu pragnie także innych nimi obdarować. Polecając go, odwołuje się do okresu swoich studiów:

„[...], to jednak przez wzgląd na nasze studia i Ateny same, a ponadto przez cześć ku naszym wspólnym ojcom krasomówstwa staraj się usilnie wobec pięknego Pronojosa podwoić swe wychowawcze wysiłki" ${ }^{\text {"53. }}$.

Chęć udzielania pomocy wstawienniczej staje się u Kapadocczyka wręcz powinnością. Nie potrafi pozostać bezczynnym, skoro tylko dowiaduje się o jakiekolwiek potrzebie kogoś spośród jego współmieszkaníców, mając świadomość, że może komuś ułatwić życie.

Najwybitniejszy retor IV wieku, słynny wówczas Libaniusz, jest odbiorcą najkrótszego listu (Ep. 236) Grzegorza. Jego charakter wstawienniczy jest tej treści:

„Ja matka ojcu posyłam dziecko, matka wedle ciała, ojcu - wedle ducha. Chcesz, bym ja o niego dbała, dbajze i ty"

\footnotetext{
so Ep. 176, PG 37, 288B, POK 15, 218.

${ }^{51}$ Ep. 177, PG 37, 289A, POK 15, 218.

${ }^{52}$ Ep. 188, PG 37, 308B, POK 15, 232.

${ }^{53}$ Ep. 189, PG 37, 308C, POK 15, 233.

54 Ep. 236, PG 37, 380A, POK 15, 282.
} 
Kontekst listu wyraźnie podpowiada, że Grzegorz napisał go w imieniu jakiejś matki, która wysyła swe dziecko na nauki do slawnego retora. Również i ten list świadczy o bliskiej zażyłości biskupa kapadockiego $\mathrm{z}$ retorem, który był poganinem. Nie przeszkadzało to jednak prosić go o pomoc.

\section{LISTY DO BISKUPÓW W SPRAWACH LUDZI SWIECKICH}

Listy do braci w biskupstwie Grzegorz pisał wówczas, gdy został biskupem, a ściślej, po powrocie z Konstantynopola w rodzinne strony, gdzie kontynuował pasterską służbę w Nazjanzie, czyli w latach 382-383. Wśród podejmowanych przez niego kwestii dających się rozstrzygnąć drogą korespondencyjną, były również i takie, które bezpośrednio dotyczyły ludzi świeckich.

Helladiusz, biskup Kapadocji Drugiej, otrzymuje listowną prośbę od Grzegorza, by zechciał wesprzeć Nikobula, kilkakrotnie już wyżej wzmiankowanego. Z listu (Ep. 127) do niego skierowanego nie można dowiedzieć się wprost, o jaką konkretną pomoc prosi Nazjanzeńczyk. Niemniej jednak list kończy się słowami:

„[...] przez ciebie jemu dług spłacam. Potrzeba mu spokoju, do którego przez cały czas przywykt. Racz mu dopomóc do tego" ${ }^{, 55}$.

Życie Nikobula Starszego, męża siostrzenicy Grzegorza, nie było łatwe, jak wynika z tych listów, które wyżej zostały zaprezentowane. Dlatego biskup prosi adresata o zapewnienie spokoju swemu krewnemu, gdyż znając jego kłopoty życiowe, nie mógł patrzeć na nie obojętnie. Grzegorz był bowiem człowiekiem wrażliwym na krzywdę ludzką.

Pomoc wstawiennicza udzielana Nikobulowi obejmowała nie tylko jego, lecz także jego dzieci. Potwierdzeniem tego jest list adresowany do Teodora, biskupa Tiany, który przebywał w Nazjanzie z racji wyborów następcy Grzegorza, przez krótki czas zasiadającego na stolicy biskupiej tego miasta. Prośba w jego (Ep. 157) brzmi następująco:

„Chłopcy najdroższego mego Nikobula wyjechali do miasta na naukę szybkopisu.

Racz przyjąć ich w ogóle serdecznie i po ojcowsku, [...]. Chciałbym, żeby ich charaktery zaprawiały się do cnoty przez ciągłą styczność z twą doskonałością" ${ }^{\prime \prime 6}$.

Być może tym miastem była Tiana, której adresat był biskupem. List pokazuje jednocześnie gorliwość Grzegorza w świadczeniu wszelkiej pomocy najbliższym, a przede wszystkim jego troskę o osiągnięcie ich duchowego rozwoju.

S5 Ep. 127, PG 37, 221B, POK 15, 169.

S6 Ep. 157, PG 37, 265A, POK 15, 201. 
Spośród dzieci Nikobula Starszego szczególną opieką Grzegorza cieszył się Nikobul, zwany Młodszym, który już wcześniej był powodem korespondencji Nazjanzeńczyka. Tym razem poleca go listownie (Ep. 167) Helladiuszowi, biskupowi Cezarei, takimi słowami:

„Oto masz upominek mojej przyjaźni: to najsłodszy syn mój Nikobul, pierwszy wśród drogich memu sercu krewnych. Łaskę mi dużą okażesz, jeśli go przedstawisz tęższym nauczycielom, a jeszcze większą, jeśli i obyczaje jego do cnoty nastroisz"57.

Nie wiadomo, dlaczego Nazjanzeńczyk musiał tak często interweniować w jego życie, polecając go swoim przyjaciołom wysoko stojącym w hierarchii społecznej. Zródłem nadmiernej opieki mógł być niestały charakter Nikobula, i w związku z tym możliwość zmarnowania posiadanych przez niego zdolności, do czego biskup kapadocki nie chciał dopuścić.

Sprawy swoich krewnych nie były Grzegorzowi obojętne, skoro powierzał je nawet braciom w biskupstwie. Nektariuszowi, biskupowi Konstantynopola, śle list (Ep. 186), w którym poleca mu swą siostrzenicę. Wstawia się w nim za nią, pisząc:

„[...] uczcij wiek błagalny, uczcij też jej charakter i pobożność, bo nie jest to niewiasta, jak inne. Uwzględnij obok innych rzeczy jej niewieścią nieobrotność i to, że kłopoty ma ze strony swych bliskich" 58 .

Grzegorz nie wymienia konkretnej sprawy krewnej, leczy prosi biskupa Konstantynopola o zaopiekowanie się nieśmiałą niewiastą, która ma pojawić się w wielkim mieście.

Wspomniany wyżej biskup Teodor z Tiany jest odbiorcą jeszcze kilku listów. W jednym z nich (Ep. 159) Nazjanzeńczyk prosi o wstawiennictwo za swą krewną Amazonią:

„Jeśli uczcisz jej wiarę, wspomożesz w chorobie ciała, jeśli dla tych powodów rękę jej we wszystkim podasz, i nią się zaopiekujesz - spełnisz szlachetny uczynek"s9.

List nie podaje, czy byla ona mieszkanką Tiany. $Z$ pewnością tak, gdyż w przeciwnym wypadku treść prośby straciłaby sens. Wspólne miejsce zamieszkania wystarczyło Grzegorzowi, by tamtejszego biskupa błagać o opiekę i pomoc dla swej krewnej, która przeżywała $\mathrm{z}$ powodu choroby trudne chwile w swoim życiu.

Grzegorz ośmielił się powierzać biskupowi Teodorowi nawet kwestie spadkowe swojej rodziny. Prosi go w kolejnym liście (Ep. 160), by zatroszczył się o sprawiedliwy podzial majątku dla swej siostrzenicy. Jego króciutki list rozpoczyna się prośbą:

\footnotetext{
${ }^{57}$ Ep. 167, PG 37, 277A, POK 15, 209.

58 Ep. 186, PG 37, 305B, POK 15, 231.

${ }^{59}$ Ep. 159, PG 37, 268A, POK 15, 202.
} 
.,I ty i ja tego chcemy, by stała się̧ sprawiedliwość córce mojej Eugenii u twej pobożności i byś nie dopuścił do krzywdzenia jej przez wspólspadkobierców" ${ }^{0}$.

Wrażliwość Grzegorza na ludzkie problemy nie pozwalała mu czekać bezczynnie na ich samorozwiązanie bądź też krzywdzące załatwienie danej sprawy. Przykład takiego postępowania wobec spadkobiorcy i reakcja biskupa potwierdza przytoczony fragment listu.

Biskup Teodor, oprócz spraw dotyczących krewnych Grzegorza, był także odbiorcą listów wstawienniczych uwzględniających potrzeby innych ludzi. Ukazuje to fragnent jednego z nich (Ep. 161):

„Inaczcj źle bym zrobił i zgrzeszył wobec twojej pobożności, jeślibym zaprowadzal do ciebie, jako sprawiedliwego sędziego, zgłaszających się do mnie ludzi, a nie zadowalał się twoim rozsądzeniem"61.

Wypowiedź ta zawiera ponadto ważną informację dla zrozumienia zakrojonej na szeroką skalę działalności wstawienniczej, prowadzonej przez Grzegorza. Mówi tu o ludziach, którzy się do niego zglaszają. Wynika z tego, że Nazjanzeńczyk byl powszechnie znany ze swej dobroduszności i niezwykłej filantropii.

Przyklad takiego postępowania zawiera również następny list (Ep. 162), którego adresatem jest także biskup Teodor, a który dowiaduje się o krzywdzie wyrządzonej wdowom:

„[...] i podaj, proszę, pomocną prawicę tym wdowom, nie przeoczaj tego, jak je tyranizuje i poniewiera swą władzą ten człowiek, przeciw któremu one wystąpily. Owszem, zaopiekuj się, jak wypada, nimi, jeśli wiesz, co cierpią i dlaczego cierpią̧,62.

Wprawdzie z listu nie można wywnioskować, na czym polegala ta krzywda, to jednak pewnym jest, że adresat odnośnie tej sprawy musiał być dobrze zorientowany. Rćwnież o tej protekcji Grzegorza zadecydował wzgląd na czlowieka i jego godność.

Misja wstawiennicza Grzegorza nie odnosiła się tylko do spraw codziennego życia, jak na przykład wsparcia materialnego, pomocy w sądach czy też opieki nad mlodymi ludźmi. Miały też miejsce prośby odnoszące się do spraw duchowych. Taka znajduje się w liście (Ep. 158) skierowanym do biskupa Eulaliusza, następcy Grzegorza w Nazjanzie, w którym została przedstawiona duchowość dziewicy Alipiany wraz z błaganiem Kapadocczyka o modlitewne wstawiennictwo:

„Wiedząc o tym, módl się za tą panienkę i podjęte przez nią zaczątki zbavienia rozwiń ku chwale Boga, ku chwale naszej i całego zboru świętych"63.

\footnotetext{
${ }^{60}$ Ep. 160, PG 37, 268A, POK 15, 202.

61 Ep. 161, PG 37, 268B, POK 15, 202.

${ }^{62}$ Ep. 162, PG 37, 268CD, POK 15, 203.

${ }^{63}$ Ep. 158, PG 37, 265B, POK 15, 201.
} 
Mimo że prośba dotyczy kwestii związanej z duchowością drugiego człowieka, dla Grzegorza ma wymiar spoleczny, ze względu na chwalę Boga i Kościola.

Analiza korespondencji Grzegorza z Nazjanzu wyraźnie wskazuje na działalność protekcyjną autora listów skierowanych do różnych wpływowych osób. Nie są jasne do końca motywy takiego postępowania biskupa, chociaż opicrając się na zamieszczonej w listach argumentacji można przychylić się do stwierdzenia bezinteresowności tych poczynan. Wiele w nich jest troski o bliźnich i o ich trudne życie. Zawarta jest chęć niesienia pomocy ludziom, którzy się do niego zglaszają. Wskazuje to na otwartość Nazjanzeńczyka na codzienne sprawy współmieszkańców Kapadocji. Autor omawianych listów żył tymi wydarzeniami, i tam, gdzie mógł pomóc, pomagał, wykorzystując do tego swoje moźliwości.

\title{
GREGORII NAZIANZENI RELATIO CUM LAICIS IN LITTERIS EIUS COMMENDATICIIS
}

\author{
(Argumentum)
}

Gregorius Nazianzenus 245 litteras scripsit. Sunt inter has 58 litterae commendaticiae, quae ad administratores publicos, amicos et episcopos scriptae sunt. Talis numerus litterarum missarum ad homines notos cognitosque in laicorum rebus indicat Gregorium plenum amoris curaeque erga indigentes fuisse. Omnibus semper ad auxilium ferendum promptus erat. 